\title{
Minjingu phosphate rock availability in low-pH highly weathered soil as affected by
}

\section{added salts}

Isaac Savini*, Saidou Koala, Job Kihara

International Center for Tropical Agriculture (CIAT), ICIPE

Duduville Campus, Kasarani, P.0. Box 823-00621 - Nairob

- Kenya.

*Corresponding author <i.savini@cgiar.org>

Edited by: Tairone Paiva Leão

Received August 20, 2014

Accepted March 23, 2015

\begin{abstract}
Concentrations and identity of ions in the soil solution may affect soil phosphorus $(P)$ reactions and $P$ availability. In this study, the magnitude of these reactions was evaluated following the application of Minjingu phosphate rock (MPR) combined with chloride and carbonate salts of $\mathrm{Na}$ and $\mathrm{Ca}$ within an incubation experiment. Twenty-one days later $\mathrm{NaOH}-\mathrm{P}$ and $\mathrm{HCl}-\mathrm{P}$ were determined. This investigation was undertaken with the aim of identifying the role of Ca-ion activity in the liquid phase on the solubilization of MPR and formation of insoluble Ca-P phases. The increase in $\mathrm{pH}$ was higher with $\mathrm{Na}_{2} \mathrm{CO}_{3}$ than with $\mathrm{CaCO}_{3}$, while both $\mathrm{CaCl}_{2}$ and $\mathrm{NaCl}$ resulted in slight decreases in $\mathrm{pH}$. The dissolution of MPR was higher overall when MPR was applied singularly than for the combined application of the phosphate rock with salts of calcium or sodium after 60 days of incubation. Dissolution of MPR decreased as levels of $\mathrm{CaCO}_{3}$ or $\mathrm{CaCl}_{2}$ increased but the decrease was more pronounced in $\mathrm{CaCO}_{3}$-treated than in $\mathrm{CaCl}_{2}$-treated soils. Ca-ion activity in the liquid phase is the main factor responsible for the insolubilization of MPR and the formation of insoluble Ca-P phases ( $\mathrm{HCl}$ P). The formation of Ca-P solid phases increased with the concentration of Ca-ions, and was governed by the $\mathrm{pH}$ and nature of the accompanying anion. For soils with low levels of exchangeable cations and where liming is a recommended intervention measure, $\mathrm{Ca}$ from lime will form insoluble $\mathrm{P}$ phases and reduce the dissolution of PR and $\mathrm{P}$ availability to plants.

Keywords: Phosphorus, anion, cation, calcium
\end{abstract}

\section{Introduction}

In Sub-Saharan Africa (SSA), phosphorus is identified as the major limiting nutrient in the vast majority of soils (Bationo et al., 1997). Such soils constitute up to 55 $\%$ of the agricultural land in SSA (Bationo et al., 1986). In Kenya, for example, Braun et al. (1997) noted that in addition to $\mathrm{P}$ deficiency, applied $\mathrm{P}$ was susceptible to fixation in about $66 \%$ of the soils in the highlands. Low content of available $\mathrm{P}$ in these soils is genetic and agriculture only tends to aggravate the process. The main strategy to cope with $\mathrm{P}$ deficiency in the tropics has been the addition of fertilizers, either in the form of synthetic fertilizer or in the form of phosphate rock (PR) (Walker and Syers, 1976; Zapata and Zaharah, 2002).

When any phosphate fertilizer is applied to the soil, several processes are initiated to control the $\mathrm{P}$ dynamics. The extent of these reactions is influenced by the physical and chemical properties of the soil (Sample et al., 1980). Water soluble fertilizers such as superphosphates are expensive and many of the less-developed countries are exploring the possibility of making maximum use of indigenous agro-minerals such as PRs, as substitutes for expensive, imported fertilizers. Therefore, an accurate determination of the PR dissolution in soils is of major importance.

Dissolution of PR in soil solution requires an adequate supply of moisture and protons $\left(\mathrm{H}^{+}\right)$, as well as the removal of reactive products such as $\mathrm{Ca}^{2+}, \mathrm{H}_{2} \mathrm{PO}_{4}^{-}$, and $\mathrm{F}^{-}$from the site of reaction. The rate of dissolution is considered to depend on the lowering of $\mathrm{Ca}^{2+}$ and
$\mathrm{H}_{2} \mathrm{PO}_{4}{ }^{-}$activities (Bolan et al., 1990; Chien et al., 1980a, b; Kanabo and Gilkes, 1987; Khasawneh and Doll, 1978; Robison et al., 1992a, b; Robinson and Syers, 1990; Wilson and Ellis, 1984). Several researchers have studied the availability of P from PR sources applied to soil (Bolan et al., 1990; Bolland and Gilkes, 1997; Chien et al., 1987; Engelstad et al., 1974); however, studies on the interaction effect of PR and different ion combinations and how they affect $\mathrm{P}$ availability and extractability are limited.

Considerable attention has been given towards the effect of liming on the agronomic effectiveness of PR materials in soil (He et al., 1996a and b; Baligar et al., 1997). From a practical standpoint it is interesting to consider how P interacts as a PR compared to soluble $\mathrm{P}$ fertilizer in limed acid soils. In this study, the interaction effect of combinations of Minjingu PR (MPR) and calcium and sodium as carbonate or chloride salt on $\mathrm{P}$ release was investigated. This can help clarify the relative importance of carbonate solid phases and other soil minerals in inducing PR partitioning between the dissolved and the solid phases. The study also investigated how the slurry concentration, $\mathrm{pH}$ and electrolyte concentration influence $\mathrm{P}$-extraction by sequential and resin methods.

\section{Materials and Methods}

Superficial samples from a Kandiudalfic Eutrudox from Maseno in western Kenya were used. A number of the properties of the soil are presented in Table 1. Phosphorus sorption isotherms determined by the Fox and 
Table 1 - Physical and chemical properties of the soils used.

\begin{tabular}{|c|c|c|}
\hline pH (1:2.5 soil/water suspension) & 5.2 & McLean (1965) \\
\hline organic carbon (C) $\mathrm{g} \mathrm{kg}^{-1}$ & 17.0 & $\begin{array}{c}\text { Nelson and Sommers } \\
\text { (1985) }\end{array}$ \\
\hline exchangeable acidity $\mathrm{mmol}_{\mathrm{c}} \mathrm{kg}^{-1}$ & 5 & McLean (1965) \\
\hline exchangeable calcium mmol $\mathrm{kg}^{-1}$ & 41 & Chapman (1965) \\
\hline exchangeable magnesium $\mathrm{mmol}_{\mathrm{c}} \mathrm{kg}^{-1}$ & 14 & Chapman (1965) \\
\hline exchangeable potassium $\mathrm{mmol}_{\mathrm{c}} \mathrm{kg}^{-1}$ & 0.8 & Chapman (1965) \\
\hline $\begin{array}{l}\text { bicarbonate-EDTA extractable P mg kg-1 } \\
\text { Volumetric water content at field } \\
\text { capacity }(\%)\end{array}$ & $\begin{array}{c}1 \\
50\end{array}$ & Okalebo et al. (1993) \\
\hline clay $\%$ & 39 & Dewis and Freitas (1989) \\
\hline sand $\%$ & 30 & Dewis and Freitas (1989) \\
\hline \multicolumn{3}{|l|}{ Mineralogy (\%) } \\
\hline kaolinite & 40 & Kihara et al. (2012) \\
\hline Quartz & 18 & Kihara et al. (2012) \\
\hline geothite & 17 & Kihara et al. (2012) \\
\hline hematite & 2 & Kihara et al. (2012) \\
\hline crandalite & 1 & Kihara et al. (2012) \\
\hline amorphous compounds & 18 & Kihara et al. (2012) \\
\hline
\end{tabular}

Kamprath (1970) method indicated that a soil solution P concentration of $0.2 \mathrm{mg} \mathrm{P} \mathrm{L}^{-1}$ corresponded to $260 \mathrm{mg}$ sorbed $\mathrm{P} \mathrm{kg}^{-1}$. The soil samples were air dried, ground and passed through a 2 -mm sieve.

Minjingu phosphate rock (MPR) (12.8\% total P (128 $\mathrm{g} \mathrm{kg}^{-1}$ ), $3.0 \%$ neutral ammonium citrate soluble P (30 g $\left.\mathrm{kg}^{-1}\right)$, and $26.9 \% \mathrm{Ca}\left(269 \mathrm{~g} \mathrm{~kg}^{-1}\right)$ from northern Tanzania, and triple superphosphate (TSP) $(20 \% \mathrm{P})\left(200 \mathrm{~g} \mathrm{~kg}^{-1}\right)$ were the sources of $\mathrm{P}$ used in this study. MPR was applied as finely ground powder ( $>90 \%$ passing through a 100mesh sieve), and TSP was applied in commercially available form after hand grinding to a fine powder.

\section{Incubation}

Bulk dry soil samples were separately incubated with 5 levels of analytical grade $\mathrm{CaCO}_{3}, \mathrm{CaCl}_{2}, \mathrm{Na}_{2} \mathrm{CO}_{3}$ and $\mathrm{NaCl}$ at 0 (deionized water), 20,40,50 or $80 \mathrm{mmol}$ $\mathrm{kg}^{-1}\left(0,1.6,3.3,4.1\right.$ or $\left.6.6 \mathrm{tha}^{-1}\right)$ for 21 and 60 days at $23 \pm 2{ }^{\circ} \mathrm{C}$ in order to investigate the effects of added cations and anions, separately, on the dissolution of MPR. The soil samples (150 g) were mixed thoroughly with either deionized water (water) or $\mathrm{CaCO}_{3}, \mathrm{CaCl}_{2} \mathrm{Na}_{2} \mathrm{CO}_{3}$ or $\mathrm{NaCl}$ in separate plastic bags, moistened to $80 \%$ of field capacity before the incubation. After a period of 21 days the soils were air-dried and ground to pass through a $2 \mathrm{~mm}$ sieve.

The $\mathrm{P}$ fertilizers were added to $150 \mathrm{~g}$ air-dry preincubated soil at rates equivalent to 0 and $91 \mathrm{mg} \mathrm{P} / \mathrm{kg}$ and once thoroughly mixed moistened with deionized water to approximately $80 \%$ of field capacity. Soil samples were incubated at this moisture level in glass bottles at $23 \pm 2{ }^{\circ} \mathrm{C}$ for 21 days before analysis of resin $\mathrm{P}$ (AER and ACER-P) and sequential-P as described below.

\section{Extraction of $\mathbf{P}$}

The extent of PR dissolution in soil was determined from increases in inorganic $\mathrm{P}$ (Pi) values, or from the $\mathrm{P}$ remaining in the undissolved $\mathrm{PR}$. The $\mathrm{Pi}$ values were calculated as the difference between the Pi extracted from unamended soil and soil amended with PR. P was extracted by using both sequential and resin P methods. The resin extraction method examined both the anion alone and anion + cation resin systems extractions (Sibbesen, 1978).

Resin extractable $\mathrm{P}$ was determined using the following resin systems: (i) anion-exchange resin (Dowex $1-\mathrm{X} 8$ ) in the bicarbonate form, designated AER; (ii) anion-exchange resin (Dowex 1-X8) (bicarbonate form) plus cation-exchange resin (hydrogen form), designated AER + CER. The cation- and anion-exchange resins were enclosed in separate nylon mesh bags $1 \mathrm{~g}$ (moist weight) of resin per bag. Anion resin extractable P (AER-P) was determined by shaking $2.5 \mathrm{~g}$ of soil for $16 \mathrm{~h}$ with 40 $\mathrm{mL}$ of deionized water and one mesh bag containing $1 \mathrm{~g}$ (moist weight) anion exchange resin in bicarbonate form (Sibbesen, 1978). Anion plus cation resin extractable P (ACER-P) was determined as for AER-P, with the addition of one mesh bag containing $1 \mathrm{~g}$ (moist weight) cation exchange resin in sodium form. The $\mathrm{P}$ adsorbed by the AER under both methods was extracted by shaking the resin bag with $20 \mathrm{~mL}$ of $0.5 \mathrm{M} \mathrm{HCl}$ for $1 \mathrm{~h}$. Phosphorus in the extracts was determined by the molybdenum blue method of Murphy and Riley (1962).

\section{$P$ fractionation}

Three extractants were examined for sequential method: (i) $0.5 \mathrm{M}$ sodium hydroxide $(0.5 \mathrm{M} \mathrm{NaOH})$ to extract dissolved and recently adsorbed $\mathrm{Pi}$ (Mackay et al., 1986); (ii) $0.5 \mathrm{M}$ sodium bicarbonate at $\mathrm{pH} 8.5$ (0.5 $\mathrm{M} \mathrm{NaHCO}_{3}$ ) to extract dissolved Pi (Olsen et al., 1954); and (iii) $1 \mathrm{M}$ hydrochloric acid $(1 \mathrm{M} \mathrm{HCl})$ to extract precipitated Ca-P and undissolved PR (Apthorp et al., 1987).

Sequentially extractable $\mathrm{P}$ with and without $\mathrm{NaCl}$ prewash was determined for treatments from 21 and 30 days by a modification of the method of Tiessen and Moir (1993). The modification involved omitting the initial resin extraction step due to the substantial solubility of solid MPR in the resin-water-soil system (Mutuo et al., 1999). Briefly, $0.5 \mathrm{~g}$ of soil was shaken for $16 \mathrm{~h}$ with $30 \mathrm{~mL}$ of $0.5 \mathrm{M} \mathrm{NaHCO}_{3}(\mathrm{pH}$ 8.5). Samples were centrifuged at $5,700 \times \mathrm{g}$ for $10 \mathrm{~min}$; an aliquot of the supernatant was acidified with $0.6 \mathrm{~mL}$ of $1.2 \mathrm{M} \mathrm{H}_{2} \mathrm{SO}_{4}$ and centrifuged for $10 \mathrm{~min}$ to precipitate organic matter.

The supernatant was then analyzed for inorganic $\mathrm{P}$ (Pi). A second aliquot was digested with acidified ammonium per sulfate in an autoclave $\left(103 \mathrm{k} \mathrm{Pa}, 121^{\circ} \mathrm{C}\right)$ for 1 $\mathrm{h}$ and then analyzed for total $\mathrm{P}(\mathrm{Pt})$. Extractable organic $\mathrm{P}(\mathrm{Po})$ was calculated as the difference between $\mathrm{P}_{t}$ and $\mathrm{P}_{\mathrm{i}}$. The soil residue was extracted with $30 \mathrm{~mL}$ of $0.1 \mathrm{M}$ $\mathrm{NaOH}$ for $16 \mathrm{~h}$. Aliquots were analysed for Pi and Pt as for the bicarbonate extract. The soil residue was then extracted with $30 \mathrm{~mL}$ of $1 \mathrm{M} \mathrm{HCl}$ for $16 \mathrm{~h}$, centrifuged as above and an aliquot analysed for Pi. P was analysed by the molybdenum blue method of Murphy and Riley (1962). 
For the measurement of changes in $\mathrm{NaOH}$ and $\mathrm{HCl} \mathrm{Pi}$ fractions following treatment applications, the soil was prewashed with $1 \mathrm{M} \mathrm{NaCl}$ for half an hour at a solid: solution ratio of $1: 100$. Pre-washing with $1 \mathrm{M} \mathrm{NaCl}$ has been proposed by Mackay et al. (1986) to remove both the solution and exchangeable $\mathrm{Ca}$ which otherwise may form $\mathrm{Ca}(\mathrm{OH})_{2}$ and $\mathrm{CaCO}_{3}$ during extraction with $0.5 \mathrm{M} \mathrm{NaOH}$ and $0.5 \mathrm{M} \mathrm{NaHCO}_{3}$, respectively, and readsorb, or coprecipitate with some of the dissolved P. After centrifuging at $10,000 \mathrm{rpm}$ for $10 \mathrm{~min}$, the supernatant solution was filtered using a $0.45 \mu \mathrm{m}$ filter and analysed for Pi (Murphy and Riley, 1962). The soil residue was subsequently shaken with $0.5 \mathrm{M} \mathrm{NaOH}$ for $16 \mathrm{~h}$ at a solid:solution ratio of 1:100. After centrifuging and filtering, the solution was analysed for Pi. Phosphorus in the extracts was determined by the molybdenum blue method of Murphy and Riley (1962).

\section{Statistical Analysis}

Statistical analyses were conducted with the general linear procedure of an SAS program (SAS Statistical Analysis System, version 6.1, 1994). An LSD test was conducted to determine significant differences of the mean values between treatments. Reference to statistical significance refers to $p<0.05$ unless otherwise noted.

\section{Results and Discussion}

\section{Effect of cations and anions on dissolution of Min- jingu PR}

Irrespective of the $\mathrm{P}$ extraction method, the ability of each salt to increase $\mathrm{P}$ in soil solution was associated with the identity of the salt, cation and anion concentration (Table 2). The two extraction methods (sequential and resin) did not always produce the same results in percentage dissolution for the same treatments. Total recovery of the $\mathrm{P}$ added by both methods of extraction was less than the $\mathrm{P}$ added for all the treatments, although most of the $\mathrm{P}$ was recovered with sequential extraction.

There was a marked difference in the extent of dissolution of MPR treated with $\mathrm{NaCl}, \mathrm{Na}_{2} \mathrm{CO}_{3}, \mathrm{CaCl}_{2}$, and $\mathrm{CaCO}_{3}$. For sequential extraction, $\mathrm{P}$ recovery followed the order: $\mathrm{MPR}$ only $>\mathrm{MPR}+\mathrm{Na}_{2} \mathrm{CO}_{3}>\mathrm{MPR}+\mathrm{NaCl}$ $>\mathrm{MPR}+\mathrm{CaCl}_{2}>\mathrm{MPR}+\mathrm{CaCO}_{3}$, while resin $\mathrm{P}$ followed the order: $\mathrm{MPR}+\mathrm{Na}_{2} \mathrm{CO}_{3}>\mathrm{MPR}$ only $>\mathrm{MPR}+\mathrm{CaCO}_{3}$ $>\mathrm{MPR}+\mathrm{NaCl}>\mathrm{MPR}+\mathrm{CaCl}_{2}$. The influence of $\mathrm{NaCl}$, $\mathrm{Na}_{2} \mathrm{CO}_{3}, \mathrm{CaCl}_{2}$, and $\mathrm{CaCO}_{3}$ on the rate and extent of MPR dissolution can be clearly (Figures 2A and B). In this case MPR was incubated with seen concentrations of $\mathrm{NaCl}, \mathrm{Na}_{2} \mathrm{CO}_{3}, \mathrm{CaCl}_{2}$, and $\mathrm{CaCO}_{3}$ for 21 days. Although the shapes of the $\mathrm{P}$ recovery curves were mostly similar for each $\mathrm{P}$ fraction, there were large differences in the amounts of MPR recovered in the various $\mathrm{Ca}$ and $\mathrm{Na}$ treatments. Minimum anion resin $\mathrm{P}$ recoveries were observed where chloride salts were added irrespective of the concentration (Figure 1). This may have important implications on the ability of extractants to predict the ability of PR to supply $\mathrm{P}$ to plants in soils receiving calcium based amendments e.g. lime.

\section{Sequential $\mathbf{P}$ fractions}

The increase in $\mathrm{NaOH}$ extractable $\mathrm{P}$ was much higher than the increase in Olsen-P (bicarbonate Pi) in the soils amended with MPR (Table 2). This is because the sorbed $\mathrm{P}$ and newly formed $\mathrm{Fe}$ and $\mathrm{Al}$ phosphates can be mostly extracted into $0.5 \mathrm{M} \mathrm{NaOH}$ (Hedley et al., 1982; Tiessen et al., 1984; Wager et al., 1986), but only a fraction can be extracted by the $\mathrm{NaHCO}_{3}$. Consistent with our findings, Alloush (2003) observed that $\mathrm{NaHCO}_{3}$ extractable P often underestimates PR dissolution. Increased PR dissolution in soils does not guarantee an increase in the amount of plant available P (Sanyal and Datta, 1991). Estimated $\mathrm{P}$ from $\mathrm{NaHCO}_{3}$ has a strong correlation with plant P uptake (Zee et al., 1987; Menon et al., 1989; Sharpley, 1991) and is thus usually assumed to be plant available (Hedley et al., 1982; Tiessen and Moir, 1993; Cross and Schlesinger, 1995). On the other hand $\mathrm{NaOH}-\mathrm{Pi}$ is often assumed to be moderately available (Hedley et al., 1982, Schmidt et al., 1996; Ivarsson, 1990).

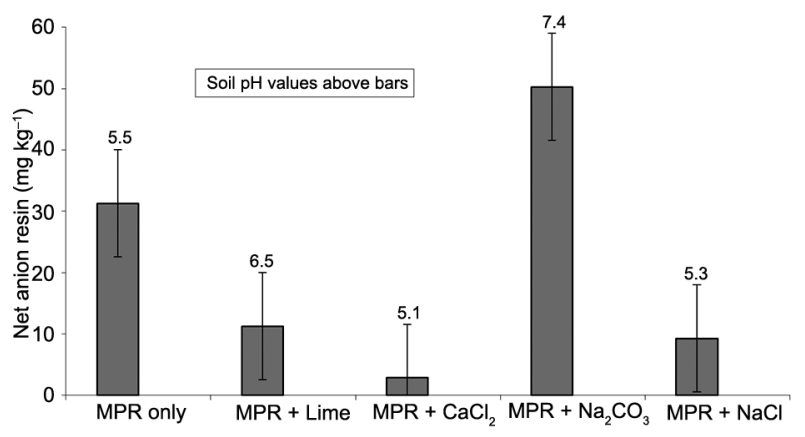

Figure 1 - Effect of added salts on $\mathrm{pH}$ and extractable anion resin $\mathrm{P}$ (means \pm standard error).

Table 2 - Minjingu phosphate rock partitioning into sequential and resin P fractions.

\begin{tabular}{|c|c|c|c|c|c|c|c|}
\hline \multirow{3}{*}{ Treatment } & \multicolumn{7}{|c|}{ Cation at 5 meq only } \\
\hline & \multicolumn{5}{|c|}{ Sequential P fractions } & \multicolumn{2}{|l|}{$\%$ recovery } \\
\hline & Net Bic Pi & Net Bic Po & $\mathrm{Net} \mathrm{NaOH} \mathrm{Pi}$ & Net $\mathrm{NaOH}$ Po & Net $\mathrm{HCl} P$ & Sequential $P$ recovery & Resin $P$ \\
\hline MPR only & 17.0 & 1.9 & 29.9 & 15.6 & 9.3 & 81 & 34 \\
\hline MPR+Lime & 4.1 & 0.6 & 9.1 & -2.1 & 28.7 & 44 & 12 \\
\hline $\mathrm{MPR}+\mathrm{CaCl}_{2}$ & 4.1 & 1.4 & 8.5 & 0.4 & 32.5 & 51 & 3 \\
\hline $\mathrm{MPR}+\mathrm{Na}_{2} \mathrm{CO}_{3}$ & 9.9 & -3.7 & 21.3 & 16.5 & 17.5 & 68 & 55 \\
\hline $\mathrm{MPR}+\mathrm{NaCl}^{2}$ & 6.2 & 2.3 & 12.8 & 11.1 & 22.7 & 61 & 10 \\
\hline
\end{tabular}


Addition of calcium or sodium salts either as carbonate or chloride decreased the concentration of $\mathrm{P}$ in the soil solution ( $\mathrm{NaOH}-\mathrm{Pi}$ ) but increased that of $\mathrm{HCl} \mathrm{P}$ (Figure 2A and $\mathrm{B}$ ). The $\mathrm{NaOH}$ Pi recovered decreased as concentrations of salts in carbonate form increased but seemed to reach saturation or stabilize at $40 \mathrm{mmol} \mathrm{kg} \mathrm{m}^{-1}$ in the case of chloride salts. That is for each sequential $\mathrm{P}$ fraction the amount of $\mathrm{P}$ recovered was dependent on both the concentration and the nature of accompanying cation and/or anion. More $\mathrm{NaOH} \mathrm{P}$ was extracted from both sodium salts of carbonate and chloride than from similar salts of calcium irrespective of the concentration (Figure 2A). This seems to agree with the Donnan prediction theory that the activity of the phosphate ion in the vicinity of the adsorbing surface (clay particles, hydroxides of iron and aluminum) should increase as the valency of the saturating cation increases (Wiklander, 1964). Thus, the accessibility of the adsorbing surface to phosphorus in solution should be greater with divalent $\left(\mathrm{Ca}^{2+}\right)$ than with monovalent $\left(\mathrm{Na}^{+}\right)$cations in the exchange complex.

Ernani and Barber (1995) have also shown that in the presence of different cations the magnitude of $\mathrm{P}$ in solution followed the descending order; $\mathrm{Na}^{+}>\mathrm{K}^{+}>$

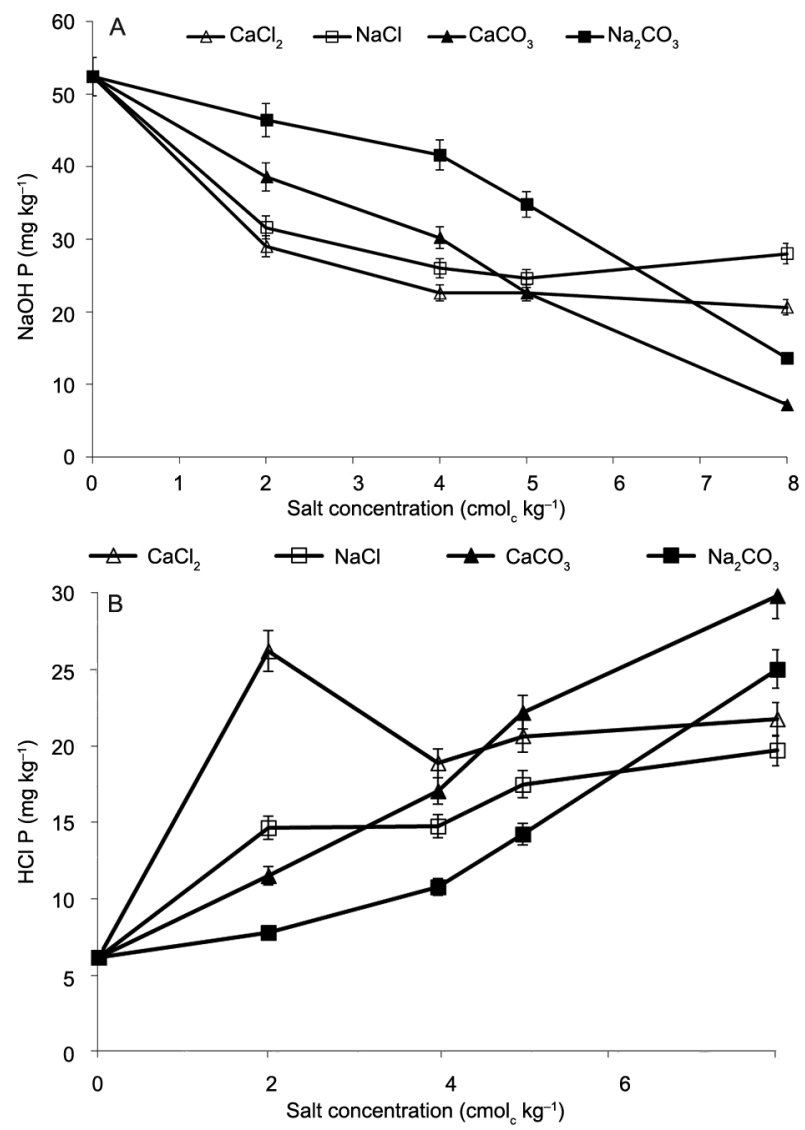

Figure 2 - Effect of added salt on MPR sequential inorganic $P$ fractions $(\mathrm{A}) \mathrm{NaOH} \mathrm{Pi}$, (B) $\mathrm{HCl} \mathrm{Pi} \mathrm{(means} \pm$ standard error).
$\mathrm{Mg}^{2+}>\mathrm{Ca}^{2+}$. The increase of $\mathrm{NaOH} \mathrm{P}$ that occurred after the addition of both sodium carbonate and sodium chloride over both salts of calcium carbonate and chloride was probably due to the diffuse double layer (DDL) effect because $\mathrm{Na}$ promotes a thicker DDL relative to calcium, and as DDL becomes thicker it is more difficult for $\mathrm{P}$ to approach the adsorption surface.

Interestingly more $\mathrm{NaOH} \mathrm{Pi}$ was extracted from both $\mathrm{NaCl}$ and $\mathrm{CaCl}_{2}$ treated soils at $80 \mathrm{mmol}_{\mathrm{c}} \mathrm{kg}^{-1}$ (Figure $2 \mathrm{~A}$ ). Furthermore, $\mathrm{pH}$ values were minimal at this concentration 4.94 and 5.22 for both $\mathrm{CaCl}_{2}$ and $\mathrm{NaCl}$ respectively (Figure 3). Bolan and Hedley (1990) reported increases in North Carolina phosphate rock, Jordan phosphate rock and Nauru phosphate rock, and dissolution when the soil $\mathrm{pH}$ decreased from 6.5 to 3.9. The dissolution of PR can be increased by increasing the supply of protons $\left(\mathrm{H}^{+}\right)$or by the continuous removal of the dissolved $\mathrm{Ca}$ and $\mathrm{P}$ from the dissolution zone (Kirk and Nye, 1986).

At low $\mathrm{pH}$, the most dissolved $\mathrm{P}$ is adsorbed by oxides of $\mathrm{Al}$ and $\mathrm{Fe}$, or precipitated as $\mathrm{Fe}$ and $\mathrm{Al}$ phosphates and $0.5 \mathrm{M} \mathrm{NaOH}$ extracts most of the $\mathrm{P}$ sorbed/precipitated with these components. Because extraction with diluted $\mathrm{NaOH}$ removes non occluded Fe-P and Al-P from a soil through desorption or solubilization (Syers et al., 1973), and because minerals of the apatite group do not dissolve to any significant extent in this reagent (Chang and Jackson, 1957), any increase in $\mathrm{NaOH}$-extractable $\mathrm{P}$ in a soil to which a PR is added should provide an estimate of the amount of $\mathrm{P}$ dissolved from the PR. Contrary to $\mathrm{NaOH}, \mathrm{P}$, recovery of the $\mathrm{HCl}$ fraction increased with increases in salt concentration (Figure 2B). Despite similar shapes of the curves of inorganic $\mathrm{P}$ across treatments, there were differences in the magnitude of $\mathrm{NaOH}$ and $\mathrm{HCl} \mathrm{P}$ extracted.

The decrease in $\mathrm{NaOH}$-extractable $\mathrm{P}$ in soil to which PR has been added with increasing concentrations of salt indicates decreased dissolution of PR. High base saturation ( $\mathrm{Ca}$ and $\mathrm{Na}$ ) also maintains soil $\mathrm{P}$ in more stable acid soluble non-extractable forms, keeping contents of the alkaline soluble secondary $\mathrm{P}$ forms low. This

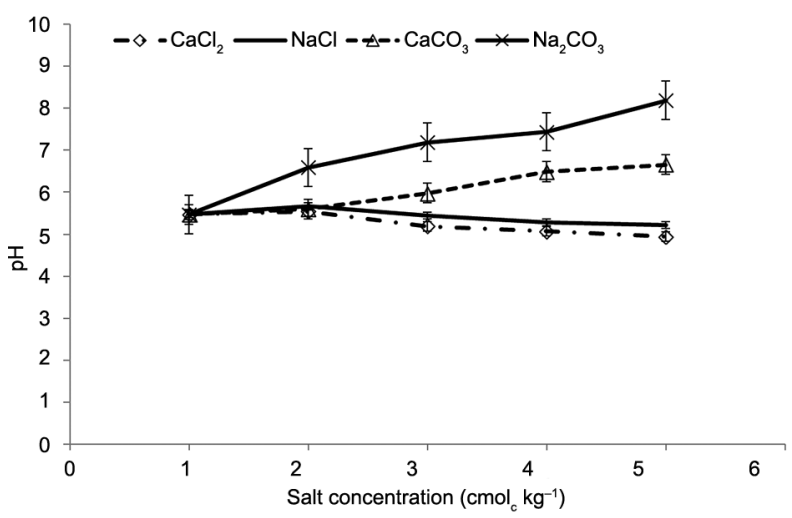

Figure 3 - Effect of added salts on soil pH (means \pm standard error). 
relationship is due to the stability of Ca-P in highly base saturated soils (Lindsay and Vlek, 1977). This is consistent with the increase in the $\mathrm{HCl} \mathrm{P}$ fraction, which is an estimate of the undissolved PR. The addition of both calcium and sodium salts (carbonates and chlorides) with MPR had significant effects on $\mathrm{HCl}-\mathrm{Pi}$ concentrations. All rates of $\mathrm{CaCl}_{2}, \mathrm{CaCO}_{3}, \mathrm{NaCl}$ and $\mathrm{Na}_{2} \mathrm{CO}_{3}$ application with MPR significantly increased the $\mathrm{HCl}-\mathrm{Pi}$ concentration in the soil (Figure 2B). This is due to the high concentration of undissolved PR ( $\mathrm{P}$ associated with $\mathrm{Ca}$ ) remaining in the soils, which was extracted by $\mathrm{HCl}$.

In general, the magnitude of the increase in $\mathrm{HCl}-\mathrm{Pi}$ concentrations per unit weight of MPR due to addition of both $\mathrm{CaCl}_{2}$ and $\mathrm{CaCO}_{3}$ was greater than that due to the corresponding $\mathrm{Na}$ form of chloride and carbonate. Since dissolution of MPR also releases $\mathrm{Ca}$, according to the mass action law or the common ion effect the dissolution of MPR will be diminished on addition of $\mathrm{CaCO}_{3}$ and $\mathrm{CaCl}_{2}$. The removal of the dissolution reaction products $\mathrm{Ca}^{2+}, \mathrm{H}_{2} \mathrm{PO}_{4}{ }^{-}$and $\mathrm{F}^{-}$from the site of dissolution and the supply of $\mathrm{H}^{+}$is a driving force for the dissolution of $\mathrm{PR}$, (Khasawneh and Doll 1978). The HCl-P results in this study are consistent with the observed increase in anion + cation resin extractable $\mathrm{P}$ where MPR was applied in combination with either $\mathrm{CaCO}_{3}$ or $\mathrm{CaCl}_{2}$ (Figure 7). The inclusion of cation exchange resin provides a sink for $\mathrm{Ca}$ thus decreasing its activity in the soil solution. This increases $\mathrm{P}$ concentrations by pulling the dissolution reaction from left to right.

$\mathrm{Ca}_{10}\left(\mathrm{PO}_{4}\right) \mathrm{F}_{2}+12 \mathrm{H}+\Leftrightarrow 10 \mathrm{Ca}^{2++}+6 \mathrm{H}_{2} \mathrm{PO}_{4}^{-}+2 \mathrm{~F}^{-}+12 \mathrm{OH}^{-}$

\section{pH and MPR solubility}

While the carbonate based salts increased the soil $\mathrm{pH}$ (alkaline), the $\mathrm{pH}$ was depressed (acidic) due to application of chloride salts (Figure 3). The two sources of soil alkalinity (calcium and sodium carbonate) had varying degrees of influence on the solubility of MPR (Figure 4A and B). Where alkalinity was entirely due to calcium, as carbonate, only $27 \%$ of the added MPR dissolved in the soil solution. On the other hand, where soil alkalinity was due to sodium, solubility increased (54\%) over that in the presence of calcium (Figure 4B). In other words, there was a rapid reduction in solubility with increases in $\mathrm{pH}$ where alkalinity was due to calcium, and an increase even in excess of the solubility generated by acid reactions, when the $\mathrm{pH}$ was raised by the addition of sodium carbonate.

In the presence of calcium carbonate, solubility fell from $46 \mathrm{mg} \mathrm{kg}^{-1}$ at $\mathrm{pH} 5.60$ to $13 \mathrm{mg} \mathrm{kg}^{-1}$ at pH 6.66 . Solubility in sodium alkalinity was high and it is interesting to note that at $\mathrm{pH} 7.4$ solubility was $31 \mathrm{mg} \mathrm{kg}^{-1}$, in sodium carbonate solution and $13 \mathrm{mg} \mathrm{kg}^{-1}$ for calcium carbonate solution.

As the $\mathrm{pH}$ changed, from 5.54 to 4.94 and 5.60 to 6.66 due to the addition of $\mathrm{CaCl}_{2}$ and $\mathrm{CaCO}_{3}$ respectively the dissolution of MPR as $\mathrm{NaOH}$ inorganic frac-
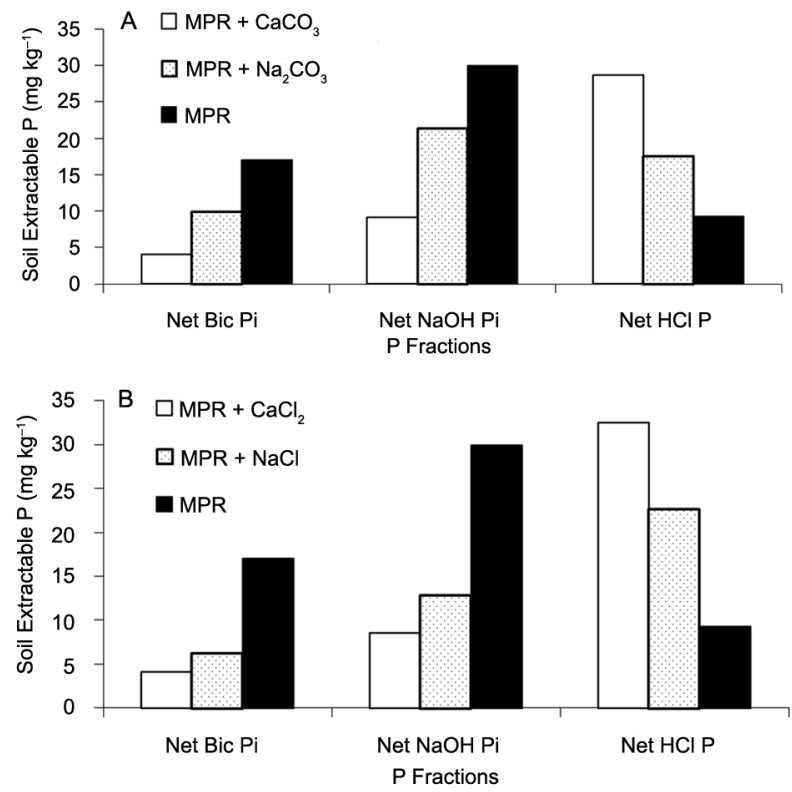

Figure 4 - Relationship between sequential inorganic $\mathrm{P}$ fractions and added salt (A) carbonate (B) chloride.

tion decreased by $10 \%$ compared to $\mathrm{CaCO}_{3}$ a decrease in $\mathrm{CaCO}_{3}$ of $38 \%$. Similarly, as the soil $\mathrm{pH}$ changed from 5.67 to 5.22 and 6.59 to 8.19 due to additions of $\mathrm{NaCl}$ and $\mathrm{Na}_{2} \mathrm{CO}_{3}$ respectively, the proportion of the dissolved $\mathrm{P}$ extracted by $\mathrm{NaOH}$ decreased by $6 \%$ in the $\mathrm{NaCl}+$ MPR combination compared to a decline of $37 \%$ when $\mathrm{Na}_{2} \mathrm{CO}_{3}$ was applied. This decrease in dissolved P corresponded to an increase in the proportion of $\mathrm{HCl}$ inorganic $\mathrm{P}$ fraction with an increase in salt concentration. However, the $\mathrm{NaOH}$ Pi from MPR plus sodium or calcium chloride relative to that from sodium or calcium carbonate was higher at low $\mathrm{pH}$ than at high $\mathrm{pH}$. Furthermore, the amount of $\mathrm{NaOH}$ extractable $\mathrm{P}$ was more closely related to the nature and amount of added salt cation than to the $\mathrm{pH}$ in the soil (Figure 4A and B). It seems that the addition of $\mathrm{Na}_{2} \mathrm{CO}_{3}$, reacts with PR (calcium phosphate) to form highly soluble sodium phosphates.

As the $\mathrm{pH}$ decreased when both calcium and sodium were added as chloride salts to the soil MPR mixture, there was an increase in $\mathrm{NaOH} \mathrm{P}$ compared to when carbonate salt of calcium and sodium were added (Figure 4A and B). The decline in $\mathrm{pH}$ accompanied by an increase in $\mathrm{NaOH}$ extractable $\mathrm{P}$ due to the addition of the chloride salts can be attributed to the role of neutral salts in increasing net positive charges that increased the adsorption of applied P (Naidu et al., 1990), in the soil. The effect of $\mathrm{pH}$ on MPR dissolution was diminished in the presence of sodium carbonate.

For Na-saturated soils, an increase in $\mathrm{pH}$ always produced a decrease in phosphate partitioning into the solid phase. This behavior can be explained by increased repulsion between phosphate anions and the surface of variable-charge minerals, such as clay edges and $\mathrm{Fe}$ 
and Al hydroxides, whose negative surface charge increases with increases in $\mathrm{pH}$. For Ca-saturated soils the effect is more complex. The dissolution of PR depends on lowering $\mathrm{H}_{2} \mathrm{PO}_{4}^{-}$activity through $\mathrm{P}$ sorption which diminishes at higher $\mathrm{pH}$ values. The $\mathrm{pH}$ affects the adsorption phenomena by influencing the repulsion in the electrical double layer. With increasing Ca concentration in solution, when precipitation becomes predominant, the effect of increasing hydroxyl ions reverses. At higher $\mathrm{pH}$ values the solubility of Ca-P mineral phases (MPR) diminishes and precipitation phenomena increase distinctly, resulting in more $\mathrm{P}$ being removed from the solution. This is evident in the increase in magnitude of the extractable $\mathrm{HCl} \mathrm{P} \mathrm{(as} \mathrm{shown} \mathrm{above)} \mathrm{and} \mathrm{mixed} \mathrm{anion} \mathrm{and}$ cation resin system (explained below) in the presence of Ca salts.

\section{Effect of added cations and anions on sequential $P$ fractions}

With the addition of $\mathrm{CO}_{3}{ }^{-2} \mathrm{NaOH} \mathrm{P}$ decreased reaching its minimum at $80 \mathrm{mmol}_{\mathrm{c}} \mathrm{kg}^{-1}$, while the presence of $\mathrm{Cl}^{-}$gradually decreased $\mathrm{NaOH} \mathrm{P}$ by up to 40 $\mathrm{mmol}_{\mathrm{c}} \mathrm{kg}^{-1}$ and showed a gradual increase thereafter (Figure 5A). The two anions gradually increased $\mathrm{HCl} \mathrm{P}$ with as concentration increased although the effect of $\mathrm{CO}_{3}^{-2}$ was stronger than $\mathrm{Cl}^{-}$(Figure 5B). While $\mathrm{Cl}^{-}$anions decreased the soil $\mathrm{pH}, \mathrm{CO}_{3}^{-2}$ had the opposite effect and increased the soil $\mathrm{pH}$. The decrease in $\mathrm{pH}$ promotes the adsorption of dissolved $\mathrm{P}$ by clays, $\mathrm{Fe}$ and Al hydroxides due to increases in the positive charge of these soilcolloidal components. The $0.5 \mathrm{M} \mathrm{NaOH}$ extracts sorbed $\mathrm{P}$ and newly formed $\mathrm{Fe}$ and $\mathrm{Al}$ phosphates which explain the increase in $\mathrm{NaOH}-\mathrm{P}$ fraction when $\mathrm{Cl}^{-}$based salts were applied.

Under conditions such as those in western Kenya, where the soils possess substantial anion exchange capacity (6 to $33 \mathrm{mmol}_{\mathrm{c}} \mathrm{kg}^{-1}$ ) (Hartemink et al., 1996), which are more preponderant than those commonly reported for variable charge soils (Hyun et al., 2003; Qafoku and Sumner 2001), more dissolved P will be adsorbed by the anion exchange sites. This is in agreement with the mineralogy of this soil (Table 1) that is dominated by sesquioxides (oxides/hydoxides of $\mathrm{Al}$ and $\mathrm{Fe}$ ) and/or 1:1 clay (kaolinite).

Generally, more $\mathrm{NaOH} \mathrm{P}$ was extracted where sodium cation was added although it showed a decline as the $\mathrm{Na}$ concentration increased (Figure 5B). The increase in $\mathrm{NaOH} \mathrm{P}$ caused by $\mathrm{Na}$ is because $\mathrm{Na}$ promotes a thicker double diffuse layer (DDL) relative to $\mathrm{Ca}$, and as DDL becomes thicker it is more difficult for $\mathrm{P}$ to approach the adsorption surface. Wiklander (1964) found that the thickness of the diffuse double layer is inversely proportional to the valency of the saturating cation. Donnan theory predicts that the activity of the phosphate ion in the vicinity of the clay particles should increase as the valency of the saturating cation increases. Thus, the accessibility of the clay surface to $\mathrm{P}$ in an adsorption reaction should be greater with divalent than with monovalent cations in the exchange complex. Pissarides et al. (1968) found that phosphate adsorption by three clay minerals (kaolinite, illite, and montmorillonite) saturated with $\mathrm{Li}, \mathrm{Na}, \mathrm{K}, \mathrm{Mg}, \mathrm{Ca}, \mathrm{Sr}$, and $\mathrm{Ba}$ was much higher for divalent than for monovalent cations. The work of Curtin et al. (1987) on 11 acidic (pH 5.56.3) New Zealand soils contrasting in P status and retention found that the release of $\mathrm{P}$ from $\mathrm{Na}$-saturated soils exceeded that from Ca-dominated soils. They explained this in terms of either enhancing the release of adsorbed phosphate following the removal of exchangeable $\mathrm{Ca}$, increased dissolution of the calcium phosphate phase present as a surface complex, or as a metastable fertilizer reaction product.

Depending on the principles of surface charge balance (Sposito, 2008; Bowden et al., 1980), the electrostatic potential of soil surfaces with a net negative charge will be more negative when the balancing cation is further from the surface. The more the negative potential in the plane of adsorption, the less the amount of phosphate adsorption. Cation characteristics which determine the closeness of the cation from the surface are valency and the degree of the hydration. This may explain our finding that more $\mathrm{P}$ was extracted by sodium
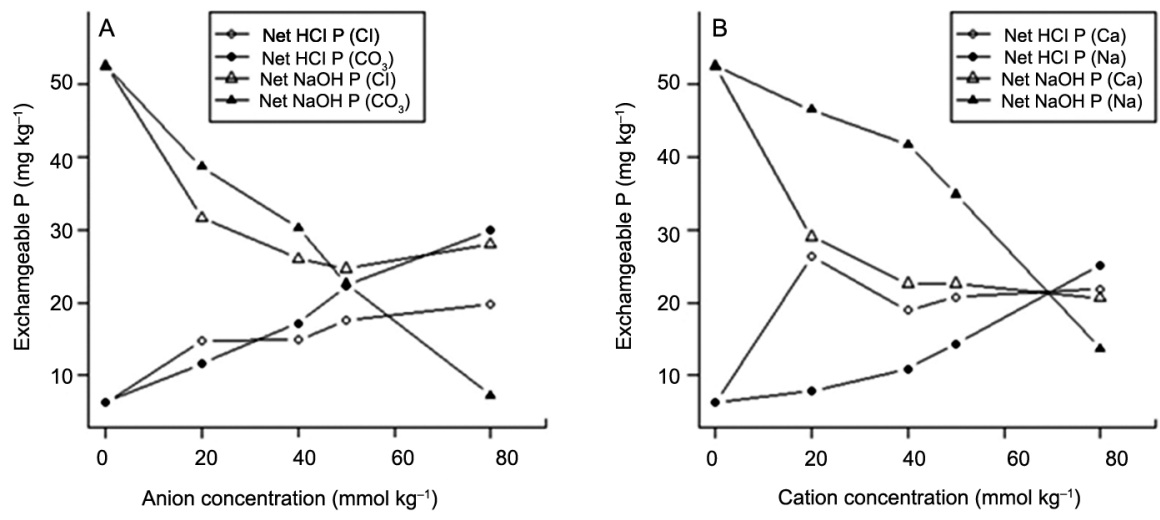

Figure 5 - Effect of anion and cation concentration on sequential inorganic $P$ fractions $(A)$ anion $(B)$ cation concentration. 
bicarbonate and sodium hydroxide when the more loosely bound $\mathrm{Na}$ ions were added compared to the addition of Ca ions. This observation is consistent with the results of the soil anion resin extractable $\mathrm{P}$ (as highlighted below) where rapid decline of $\mathrm{P}$ in solution was observed in the presence of $\mathrm{Ca}^{2+}$ and $\mathrm{Cl}^{-}$ions. This is supported by the increase in anion resin extractable $\mathrm{P}$ in the treatments when $\mathrm{Na}_{2} \mathrm{CO}_{3}$ was added. For Ca-saturated soils either by $\mathrm{CaCl}_{2}$ or $\mathrm{CaCO}_{3}$, an increase in concentration always produced an increase in phosphate partitioning into the solid phase as $\mathrm{HCl}$ fraction.

The supply of $\mathrm{H}^{+}$is a driving force for the dissolution of $\mathrm{PR}$, along with the removal of the dissolution reaction products $\mathrm{Ca}^{2+}, \mathrm{H}_{2} \mathrm{PO}_{4}^{-}$and $\mathrm{F}^{-}$from the site of dissolution (Khasawneh and Doll 1978). The PR dissolution releases stoichiometric quantities of calcium ions into soil solution, which remain in the soil as exchangeable Ca (Khasawneh and Doll 1978). The presence of $\mathrm{CaCO}_{3}$ has been shown to inhibit the dissolution of PR (Mackay and Syers, 1986) and this is due to both a Cacommon ion effect and an increase in $\mathrm{pH}$ caused by carbonate dissolution. Bolan and Hedley (1990) reported increases in the dissolution of North Carolina phosphate rock, Jordan phosphate rock and Nauru phosphate rock in allophanic soils in New Zealand, when the soil pH decreased from 6.5 to 3.9 .

\section{Resin extractable $\mathbf{P}$}

The effect of added salts on anion resin-extractable $\mathrm{P}$ was less pronounced and in the opposite direction to that on sequential $\mathrm{P}$ (Figure 6). Values of resin $\mathrm{P}$ were highly correlated with the $\mathrm{NaOH} \mathrm{P}$ fraction after addition of $\mathrm{CaCO}_{3}, \mathrm{NaCl}$ and $\mathrm{CaCl}_{2}\left(\mathrm{r}^{2}=0.97,0.99\right.$, 0.83 respectively), except when $\mathrm{Na}_{2} \mathrm{CO}_{3}$ was added $\left(\mathrm{r}^{2}\right.$ $=0.03)$. The trend was similar for the highly correlated regression analysis of resin $\mathrm{P}$ with $\mathrm{HCl} \mathrm{P}$ after addition of $\mathrm{CaCO}_{3}, \mathrm{NaCl}$ and $\mathrm{CaCl}_{2}\left(\mathrm{r}^{2}=0.99,0.97,0.69\right.$ respectively) was also observed. There was a small increase in anionic resin $\mathrm{P}$ as $\mathrm{Na}_{2} \mathrm{CO}_{3}$ concentration increased, but decreased after $50 \mathrm{mmol}_{\mathrm{c}} \mathrm{kg}^{-1}$ (Figure 6). The decreasing

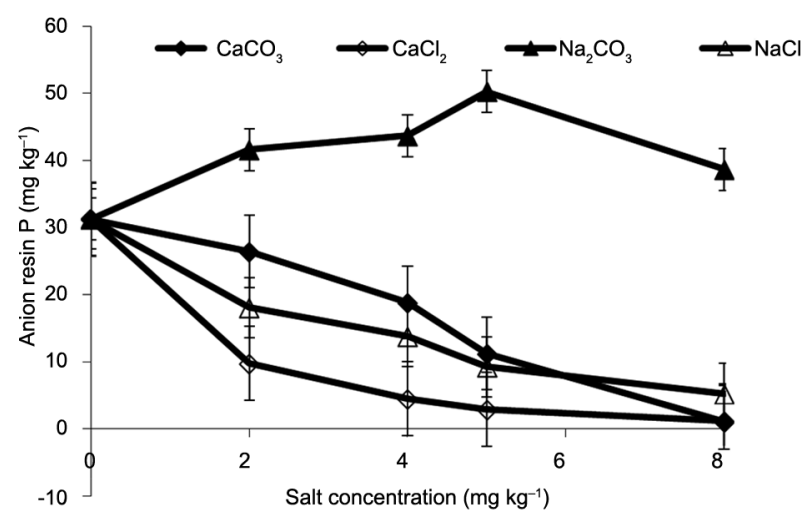

Figure 6 - Effect of salt addition on anion resin extractable P (means \pm standard error). resin extractable $\mathrm{P}$ declined as concentrations of $\mathrm{NaCl}$, $\mathrm{CaCl}_{2}$, and $\mathrm{CaCO}_{3}$ increased suggesting that dissolution of PR decreased as the concentration of chloride and calcium increased..

Alternatively, this might suggest that secondary reactions were occurring between the soil and $\mathrm{P}$ released from PR. Consistent with this, the amount of $\mathrm{P}$ extracted with $0.5 \mathrm{M} \mathrm{NaOH}$ decreased and $1 \mathrm{M} \mathrm{HCl}$ increased as the concentration of $\mathrm{NaCl}, \mathrm{Na}_{2} \mathrm{CO}_{3}, \mathrm{CaCl}_{2}$ and $\mathrm{CaCO}_{3}$ increased (Figure 2A and $\mathrm{B}$ ) and accounted for the dissolved and residual PR remaining in the soil, respectively. However, calcium and chloride ions were the main influence on $\mathrm{P}$ recovery in the resin system.

$\mathrm{CaCO}_{3}$ inhibits the dissolution of PR (Mackay and Syers, 1986) due to both a Ca-common ion effect and an increase in $\mathrm{pH}$ caused by carbonate dissolution. The effect of suspension $\mathrm{pH}$ on PR dissolution supports the hypothesis of $\mathrm{P}$ precipitation induced by soluble $\mathrm{Ca}$-ions. For Na-saturated soils $\left(\mathrm{Na}_{2} \mathrm{CO}_{3}\right)$, an increase in $\mathrm{pH}$ always produced a decrease in phosphate partitioning into the solid phase. The increase in the soil solution $\mathrm{P}(\mathrm{Pi})$ that occurred after addition of $\mathrm{Na}_{2} \mathrm{CO}_{3}$ can be explained by assuming that $\mathrm{Pi}$ is controlled to a larger extent by the surface negative charge than by precipitation reactions. Thus, the increase in negative charge that occurs after addition of $\mathrm{Na}_{2} \mathrm{CO}_{3}$ would restrict $\mathrm{P}$ adsorption.

Assuming that $\mathrm{P}$ is preferentially adsorbed by sites with the more positive potential, as proposed by Barrow and Ellis (1986), P adsorption would be restricted by a decrease in the positive surface potential that occurs after the addition of salts. However, the diminished PR dissolution with $\mathrm{CaCO}_{3}$ can be attributed to precipitation phenomena in which the suspension $\mathrm{pH}$ and the $\mathrm{Ca}$ solution influence the PR dissolution. When the Ca concentration in the solution is increased as well as higher $\mathrm{pH}$ values with $\mathrm{CaCO}_{3}$, the solubility of Ca-P mineral phases (PR) diminishes and precipitation phenomena increase distinctly, thus inhibiting PR dissolution.

To demonstrate the inhibitory effect of Ca on PR dissolution, a mixed resin system (AER + CER) was used for $\mathrm{P}$ extraction in treatments with calcium carbonate or calcium chloride. The use of AER + CER increased the resin extractable $\mathrm{P}$ in all the treatments in comparison to AER-P. The increase was highest when MPR was applied in combination with $\mathrm{CaCO}_{3}$ (Figure 7). In the $\mathrm{AER}+\mathrm{CER}$ extraction system, the removal of calcium reduces the supply of Ca-ions in solution coming either from MPR and $\mathrm{CaCO}_{3}$ solubilization or $\mathrm{Ca}^{2+}$ exchange, thus reducing precipitation processes. The average increase in AER + CER-P due to incorporation of $\mathrm{CaCO}_{3}$

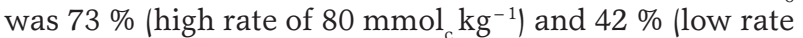
of $50 \mathrm{mmol}_{\mathrm{c}} \mathrm{kg}^{-1}$ ) relative to no Ca. However, treatments that received MPR plus $\mathrm{CaCl}_{2}$ showed similar trends of reduced $\mathrm{P}$ extraction as with AER-P but with a different magnitude (Figure 7).

Mixed resin system (AER + CER) increased extractable $\mathrm{P}$ by $39 \%\left(50 \mathrm{mmol}_{\mathrm{c}} \mathrm{kg}^{-1}\right)$ and $65 \%$ (80 $\mathrm{mmol}_{\mathrm{c}}$ $\mathrm{kg}^{-1}$ ) over anion resin system (AER) when $\mathrm{CaCl}_{2}$ was 


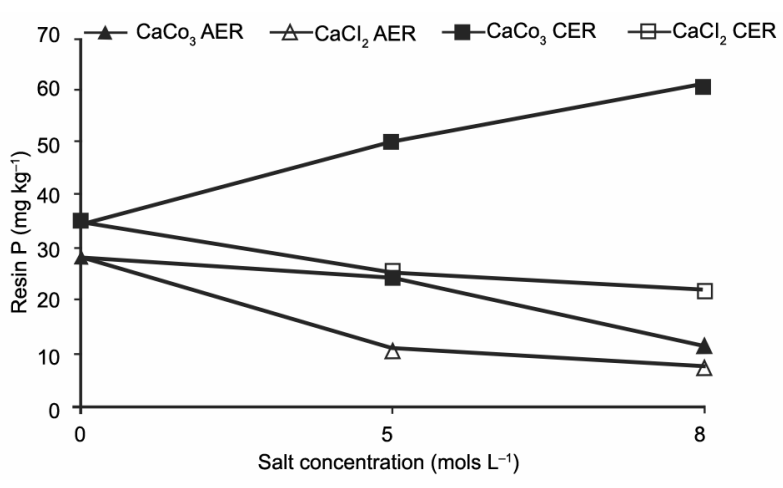

Figure 7 - Effect of carbonate and chloride anions on cation + anion (AER + CER) resin extractable $\mathrm{P}$ and anion resin (AER) P (means \pm standard error).

added to MPR. The $\mathrm{P}$ extractability trend for the anion resin system was $\mathrm{PR}+\mathrm{CaCO}_{3}>\mathrm{PR}+\mathrm{CaCl}_{2}$, while the mixed resin system (AER + CER) also followed a similar pattern but with a different magnitude ((AER + CER) > AER) (Figure 6). Resins generally function as sinks for ions in the medium; the acid cation exchange resins used here have a greater affinity for Ca ions compared with $\mathrm{H}$ counter ion initially present in the resin. PR dissolution is controlled largely by the size of the sink for solution Ca (Robinson et al., 1992b). As the proportion of Ca adsorbed by the cation exchange resin increased more PR dissolved releasing more $\mathrm{P}$ into the solution. This suggests that the effect of $\mathrm{CaCO}_{3}$ on PR dissolution is likely to depend on the Ca-sink size of the soil. The inclusion of the cation-anion resin system increased the Ca-sink size thus promoting MPR dissolution. This is a possible phenomenon/mechanism of increased $\mathrm{P}$ extraction where the mixed resin system was used. Tunesi et al. (1999) in supernatant experiments, where soil minerals were removed to reduce the supply of Ca-ions in solution coming either from $\mathrm{CaCO}_{3}$ solubilization or $\mathrm{Ca}^{2+}$ exchange, significantly reduced $\mathrm{P}$ precipitation processes.

Unlike $\mathrm{NaOH} \mathrm{P}$ concentrations, (a measure of $\mathrm{P}$ strongly adsorbed onto $\mathrm{Fe}, \mathrm{Al}$ oxides and kaolinitic clay), resin $\mathrm{P}$ concentrations, a measure of weakly adsorbed $\mathrm{P}$ exchangeable by $\mathrm{HCO}_{3}{ }^{-}$in the resin, was lower in all the treatments ( Table 2).

This is probably because the addition of $\mathrm{CaCl}_{2}$ lowered the soil $\mathrm{pH}$, which generally increases the $\mathrm{P}$ sorption capacity of the soil (Mackay and Syers, 1986). Low $\mathrm{pH}$ and increased P-fixation will promote more PR dissolution, and therefore more $\mathrm{P}$ is in $\mathrm{Al}$ and $\mathrm{Fe}-\mathrm{P}$ form which is not extracted with substantially increased efficiency by anion exchange resin. . This is consistent with the increased $\mathrm{NaOH} \mathrm{Pi}$ extraction where either $\mathrm{NaCl}$ or $\mathrm{CaCl}_{2}$ was applied (Table 2).

Additionally, the above results are a phenomenon of the resin-soil system, specifically the accompanying anions in the $\mathrm{Ca}$ and $\mathrm{Na}$ treatments. In this scenario, the generally lower P extracted by both AER and AER + CER where $\mathrm{CaCl}_{2}$ and $\mathrm{NaCl}$ was applied could be attributed to a $\mathrm{Cl}$ effect. The strongly basic anion-exchange resins of the type used in this study show a specific and strong preference for $\mathrm{Cl}$ ions over orthophosphate ions (Christensen and Posner, 1980). These basic resins in the presence of high affinity counter ions $\left(\mathrm{Cl}^{-}\right)$are ineffective sinks for use in P studies. Savini et al. (2006) in an attempt to separate the relative contribution of $\mathrm{Ca}$ versus $\mathrm{Cl}$ effects on resin $\mathrm{P}$ extraction, have also shown that bicarbonate saturated anion resin extracted more $\mathrm{P}$ from TSP treated with $\mathrm{Na}_{2} \mathrm{CO}_{3}$ and $\mathrm{CaCO}_{3}$ than where $\mathrm{NaCl}$, and $\mathrm{CaCl}$ was applied. They explained this in terms of the high concentration of complementary anions (chloride $\left(\mathrm{Cl}^{-}\right)$and the carbonate $\left.\left(\mathrm{CO}_{3}^{-}\right)\right)$inhibiting efficient extraction of soil $\mathrm{P}$ by the resin system.

Unlike the $\mathrm{Cl}^{-}$ion, the $\mathrm{CO}_{3}{ }^{-}$ion overcomes the complementary anion effect to some extent because $\mathrm{CO}_{3}$ is not conserved in solution. The carbonate ion is an ampholytic anion and may hydrolyze as shown below:

$\mathrm{CO}_{3}{ }^{2-}+2 \mathrm{H}_{2} \mathrm{O} \rightarrow \mathrm{H}_{2} \mathrm{CO}_{3}+2 \mathrm{OH}^{-}$

The considerable rise in $\mathrm{pH}$ for the lime-treated soils shows that the above route of reaction occurs. Conversely, at lower $\mathrm{pH}$ as in the $\mathrm{Cl}^{-}$-treated soil, more $\mathrm{P}$ is in $\mathrm{Al}$ and $\mathrm{Fe}-\mathrm{P}$ form which is not extracted with substantially increased efficiency by the resin system. This was supported by the increase in the $\mathrm{NaOH} \mathrm{P}$ fraction where $\mathrm{Cl}^{-}$was applied.

\section{Effect of cations and anions on resin extractable $P$}

Combined CERs/AERs are becoming increasingly popular as multi-element extractants for soils. Resins have the advantage of more closely simulating ion uptake characteristics of plant roots and correlations of resin extractable elements in soil with plant growth have generally been superior to those obtained using other chemical extractants (Skogley et al., 1990; Qain et al., 1992). Addition of $\mathrm{Na}$ salts gave a similar pattern of anion resin extractable $\mathrm{P}$ for $\mathrm{NaCl}+\mathrm{TSP}, \mathrm{Na}_{2} \mathrm{CO}_{3}+\mathrm{MPR}$ and $\mathrm{Na}_{2} \mathrm{CO}_{3}+\mathrm{TSP}$ although with a different magnitude (Figure 8A).

The trend of anion resin extractable $\mathrm{P}$ after addition of $\mathrm{Ca}$ salts was $\mathrm{CaCO}_{3}+\mathrm{TSP}>\mathrm{CaCl}_{2}+\mathrm{TSP}>$ $\mathrm{CaCO}_{3}+\mathrm{MPR}>\mathrm{CaCl}_{2}+\mathrm{MPR}$ (Figure 8B). Values of anion resin $\mathrm{P}$ were highly correlated with the amounts of $\mathrm{Ca}$ in the soil solution determined after application of the salts $\left(r^{2}=0.94\right)$. When values for the treatments with salts containing carbonate $\left(\mathrm{CaCO}_{3}\right.$ and $\left.\mathrm{Na}_{2} \mathrm{CO}_{3}\right)$ were dropped from the regression analysis of bicarbonate $\mathrm{P}$ with resin $\mathrm{P}$ and $\mathrm{NaOH} \mathrm{P}$ with resin $\mathrm{P}$, the coefficients of correlation increased from 0.40 to 0.56 and 0.54 to 0.92 respectively. A similar $(p<0.05)$ increase in the coefficients of correlation was observed with the removal of salts containing sodium from the regression analysis $(0.4$ to 0.62 and 0.5 to 0.99 for bicarbonate $\mathrm{P}$ with resin $\mathrm{P}$ and $\mathrm{NaOH} \mathrm{P}$ with resin $\mathrm{P}$ respectively). However, the increase in the correlation coefficients was 
more significant after exclusion of the treatment values with sodium rather than carbonate.

Cation characteristics which determine the closeness of surface approach are valence and degree of hydration. Replacement of Ca by the more loosely bound $\mathrm{Na}$ ion would, therefore, lead to desorption of P. Interestingly, soil incubated with $\mathrm{PR}+\mathrm{Na}_{2} \mathrm{CO}_{3}$ increased $(p<$ 0.05) resin-Pi concentrations for both MPR and TSP (Figure $8 \mathrm{C}$ ). The magnitude of the increase in resin-Pi concentration due to the addition of MPR was similar due to the TSP addition to all the $\mathrm{NaCO}_{3}$ concentration (Figure $8 \mathrm{C}$ ). However, low extractability of MPR resin $\mathrm{P}$ was observed when calcium chloride, calcium carbonate
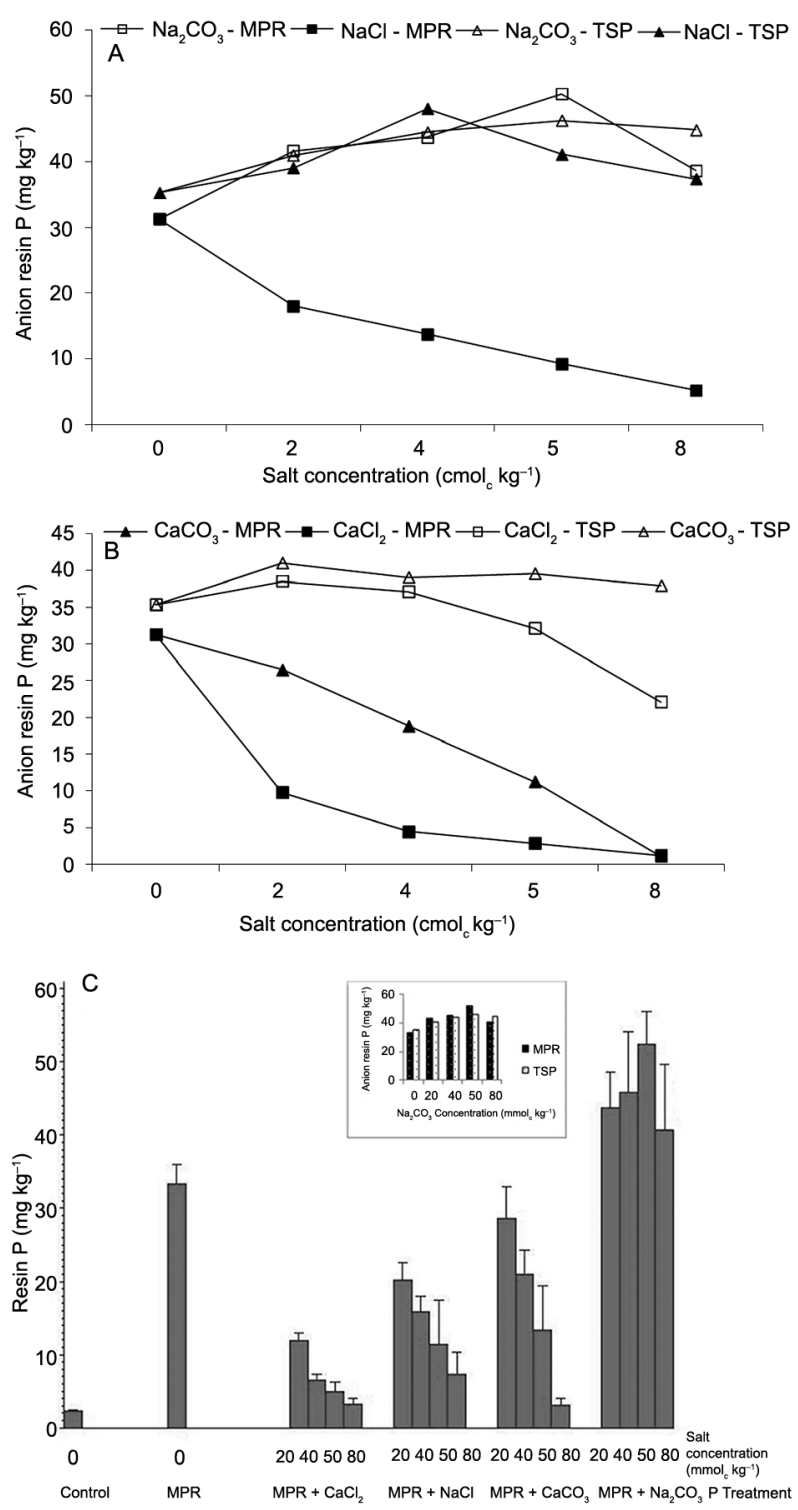

Figure 8 - Effect of added salt on Minjingu phosphate rock and Triple Super phosphate anion resin $\mathrm{P}(\mathrm{A}) \mathrm{Na}_{2} \mathrm{CO}_{3}$ and $\mathrm{NaCl}(\mathrm{B}) \mathrm{CaCO}_{3}$ and $\mathrm{CaCl}_{2}(\mathrm{C})$ salt concentration. or sodium chloride was added. The resin-Pi concentrations showed a decrease with the increase in the application rates of $\mathrm{CaCl}_{2}$ and $\mathrm{NaCl}$ for $\mathrm{MPR}$, but the rate of decrease was higher for the $\mathrm{CaCl}_{2}$ treatment than for the $\mathrm{NaCl}$ treatment (Figure $8 \mathrm{C}$ ). Therefore, a determining role in the dissolution of phosphate rock is played by calcium ions made available either from the exchange complex or from the $\mathrm{PR} /$ calcite dissolution. We suggest that the high correlation $\left(\mathrm{r}^{2}=0.99\right)$ found between AER + CER extractable $\mathrm{P}$ and the $\mathrm{CaCO}_{3}$ concentration in soil might be due mainly to the contribution of this solid phase in maintaining levels of exchangeable calcium sufficient to inhibit MPR dissolution or induce P precipitation.

The contribution of several chemical processes to the partitioning of PR between solid and liquid phases can be summarized by: (i) adsorption on mineral components, such as clays, and hydroxides; and (ii) precipitation from solution, when solubility products for phosphate solid phases are exceeded by increasing concentrations of exchangeable cations such as Ca-ions; this process is strongly influenced by $\mathrm{pH}$. The relationships proposed to describe how added Ca salts partitions PR into different $\mathrm{P}$ fractions $(\mathrm{P}$ in solution, Ca-precipitate and undissolved PR) and the estimation level of different $\mathrm{P}$ fractions in the soil-PR system are summarized in Figure 9.

\section{Effect of NaCl-prewash on recovery of dissolved $P$}

Syers et al. (1973) have suggested that $1 \mathrm{M} \mathrm{NaCl}$ extraction should be used prior to alkaline extractants in sequential $\mathrm{P}$ fractionation schemes. The $1 \mathrm{M} \mathrm{NaCl}$ prewash removes exchangeable $\mathrm{Ca}$ thereby preventing the formation of $\mathrm{Ca}(\mathrm{OH})_{2}$ in the $0.5 \mathrm{M} \mathrm{NaOH}$ extracts, which could readsorb $\mathrm{P}$ or coprecipitate with extracted soil Pi. The effect of prewashing the soils used in this study with $1 \mathrm{M} \mathrm{NaCl}$ on $0.5 \mathrm{M} \mathrm{NaOH}$ and $0.5 \mathrm{M} \mathrm{NaH}$ $\mathrm{CO}_{3}$ extractants on the measurement of PR dissolution is presented in Table 3. The calculated amount of PR dissolved with $\mathrm{NaCl}$ prewash was significantly affected only where $\mathrm{CaCl}_{2}$ was applied (Table 3). The subsequent increase in $0.5 \mathrm{M} \mathrm{NaOH}$ and decrease in $1 \mathrm{M} \mathrm{HCl} \mathrm{ex-}$ tractable $\mathrm{P}$ apparently results from the decrease in ionic strength and the replacement of exchangeable $\mathrm{Ca}$ and $\mathrm{Mg}$ by $\mathrm{Na}$.

The prewash with $\mathrm{NaCl}$ removes $\mathrm{Ca}$ and avoids the formation of $\mathrm{Ca}(\mathrm{OH})_{2}$ during the $\mathrm{NaOH}$ extraction, a fact confirmed by the greater $\mathrm{P}$ recoveries by the $\mathrm{NaOH}$ solution compared to the $\mathrm{P}$ recoveries in the absence of a prewash. Non-significant increases in the $\mathrm{NaOH}$ $P$ recoveries, except where $\mathrm{CaCl}_{2}$ was added, suggests that $\mathrm{P}$ is unlikely to be adsorbed by either $\mathrm{Ca}(\mathrm{OH})_{2}$ or $\mathrm{CaCO}_{3}$ precipitates or that these precipitates did not form during the extraction of this soil. Further, in acidic soils it is likely that the levels of exchangeable $\mathrm{Ca}$ are low and thus $1 \mathrm{M} \mathrm{NaCl}$ pre-extraction is not required for the measurement of PR dissolution by $0.5 \mathrm{M} \mathrm{NaOH}$ method. 


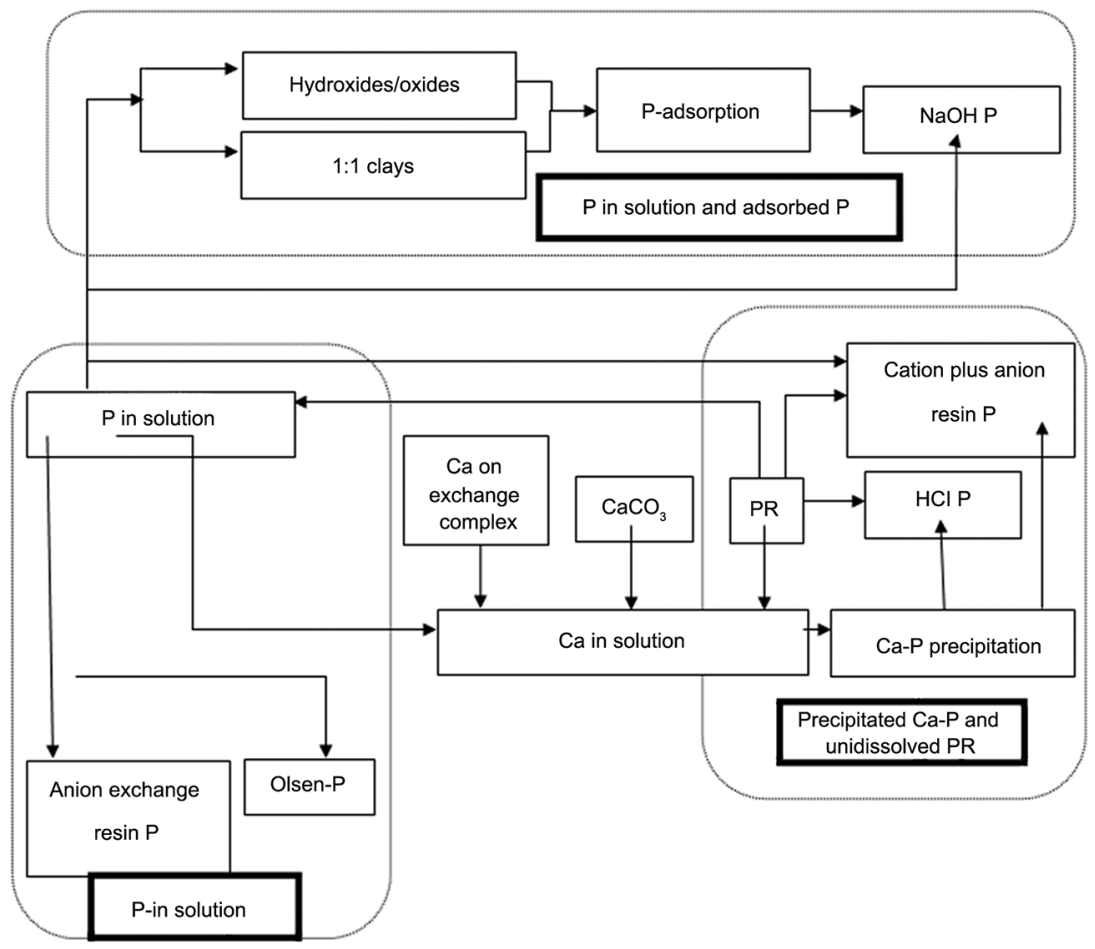

Figure 9 - Scheme summarizing phosphate rock partitioning in limed acidic soils.

Table 3 - Effect of $\mathrm{NaCl}$ prewash on inorganic $\mathrm{NaOH}$ extractable $\mathrm{P}$.

\begin{tabular}{|c|c|c|c|c|c|}
\hline Days & Treatment & $\begin{array}{c}\mathrm{NaHCO}_{3} \mathrm{Pi}+ \\
\mathrm{NaOH} \text { Pi (without } \\
\mathrm{NaCl} \text { Prewash) }\end{array}$ & $\begin{array}{c}\mathrm{NaHCO}_{3}+\mathrm{NaOH} \\
\text { Pi (with } \mathrm{NaCl} \\
\text { Prewash) }\end{array}$ & Difference & Sig \\
\hline 21 & $\mathrm{CaCl}_{2}$ & 54.85 & 54.37 & -0.48 & ns \\
\hline 21 & Control & 54.28 & 55.37 & 1.09 & ns \\
\hline 21 & $\mathrm{CaCO}_{3}$ & 53.44 & 53.88 & 0.44 & ns \\
\hline 21 & MPR & 99.77 & 104.19 & 4.42 & ns \\
\hline 21 & $\mathrm{MPR}+\mathrm{CaCl}_{2}$ & 73.1 & 78.77 & 5.67 & * \\
\hline \multirow[t]{4}{*}{21} & $\mathrm{MPR}+\mathrm{CaCO}_{3}$ & 59.45 & 61.07 & 1.62 & ns \\
\hline & d.f. & & 34 & & \\
\hline & s.e.d. & & 2.742 & & \\
\hline & I.s.d. & & 5.573 & & \\
\hline 30 & $\mathrm{CaCl}_{2}$ & 58.75 & 61.05 & 2.3 & ns \\
\hline 30 & Control & 59.37 & 60.65 & 1.28 & ns \\
\hline 30 & $\mathrm{CaCO}_{3}$ & 57.82 & 57.94 & 0.12 & ns \\
\hline 30 & MPR & 120.21 & 122.53 & 2.32 & ns \\
\hline 30 & $\mathrm{MPR}+\mathrm{CaCl}_{2}$ & 89.08 & 97.24 & 8.16 & * \\
\hline \multirow[t]{4}{*}{30} & $\mathrm{MPR}+\mathrm{CaCO}_{3}$ & 74.21 & 79.04 & 4.83 & ns \\
\hline & d.f. & & 34 & & \\
\hline & s.e.d. & & 2.5 & & \\
\hline & I.s.d. & & 5.081 & & \\
\hline
\end{tabular}

MPR = Minjingu phosphate rock; ns= non significant; * Significant at $5 \%(p<$ 0.05); d.f. = degree of freedom; s.e.d. = standard error of difference; I.s.d.= least significant difference.

The current study reaffirms the need to remove $\mathrm{Ca}$ when evaluating the PR dissolution through alkaline extractions. Precipitation and insolubilization processes become dominant under increasing concen- trations of calcium ions released from the exchange complex or solubilized from either carbonate or PR phases. The calcium released governs the insolubilization of phosphates, due to the low solubility of Ca-P solid phases.

We can conclude that concentration and identity of cations and anions in the soil solution may affect soil $\mathrm{PR}$ reactions and thus $\mathrm{P}$ availability. If solution mediated processes predominate in PR treated soils, agronomic practices which enrich the soil solution with reactants able to form Ca-complexes may be very important to increasing $\mathrm{P}$ availability to plants.

The interactive effects of $\mathrm{PR}$, exchangeable cations and $\mathrm{pH}$ need to be taken into account when they are used in agriculture. The nature of the accompanying cation and $\mathrm{pH}$ were the main determinants of $\mathrm{P}$ recovery with sequential extraction.

\section{Acknowledgements}

This study was supported by a grant from the International Center for Tropical Agriculture - Tropical Soil Biology Fertility (CIAT-TSBF) and World Agroforestry Center.

\section{References}

Alloush, G.A. 2003. Dissolution and effectiveness of phosphate rock in acidic soil amended with cattle manure. Plant and Soil 251: 37-46. 
Apthorp, J.N.; Hedley, M.J.; Tilman, R.W. 1987. The effect of nitrogen fertilizer form on the plant availability of phosphate from soil, phosphate rock and monocalcium phosphate. Fertilizer Research 12: 269-284.

Baligar, V.C.; He, Z.L.; Martens, D.C.; Ritchey, K.D. 1997. Effect of phosphate rock, lime, and cellulose on ryegrass in an acidic soil. Plant and Soil 195: 129-136.

Barrow, N.J.; Ellis, A.S. 1986. Testing a mechanistic model. II. The effect of $\mathrm{pH}$ on fluoride retention by a soil. Journal of Soil Science 37: 287-293.

Bationo, A.; Mughogho, S.K.; Mokwunye, A.U. 1986. Agronomic evaluation of phosphate fertilizers in tropical Africa. p. 283318. In: Mokwunye, A.U.; Vlek, P.L.G., eds. Management of nitrogen and phosphorus fertilizers in sub-Saharan Africa. Martinus Nijhoff, Dordrecht, The Netherlands.

Bationo A., E. Ayuk, D. Ballo, and M. Koné. 1997. "Agronomic and Economic Evaluation of Telemsi Phosphate Rock in Different Agroecological Zones of Mali." Nutrient Cycling in Agroecosystems, 48:179-189.

Bolan, N.S.; Hedley, M.J. 1990. Dissolution of phosphate rocks in soils. 2. Effect of $\mathrm{pH}$ on the dissolution and plant availability of phosphate rock in soil with $\mathrm{pH}$ dependent charge. Fertilizer Research 24: 125134

Bolan, N.S.; White, R.E.; Hedley, M.J. 1990. A review of the use of phosphate rocks as fertilizers for direct application in Australia and New Zealand. Australian Journal of Experimental Agriculture 30: 297-313.

Bolland, M.D.A.; Gilkes, R.J. 1997. The agronomic effectiveness of reactive phosphate rocks, 2 . Effect of phosphate rock reactivity. Australian Journal of Experimental Agriculture 37: 937-946.

Bowden, J.W.; Posner, A.M.; Quirk, J.P. 1980. Adsorption and charging phenomena in variable charge soils. p. 147-166. In: Theng, B.K.G., ed. Soils with variable charge. New Zealand Society of Soil Science, Lower Hutt, New Zealand.

Braun, A.R.; Smaling, E.M.A.; Muchugu, E.I.; Shepherd, K.D.; Corbett, J.D., eds. 1997. Maintenance and Improvement of Soil Productivity in the Highlands of Ethiopia, Kenya, Madagascar and Uganda: An Inventory of Spatial and Non-Spatial Survey and Research Data on Natural Resources and Land Productivity; African Highlands Initiative. International Centre for Research in Agroforestry, Nairobi, Kenya. (AHI Technical Report Series, 6).

Chang, S.C.; Jackson, M.L. 1957. Fractionation of soil phosphorus. Soil Science 84: 133-144.

Chapman, H.D. 1965. Cation exchange capacity. p. 891-901. In: Black, C.A.; Evans, D.D.; Ensminger, L.E.; White, J.L.; Clark, F.E., eds. Methods of soil analysis. Part 2. American Society of Agronomy, Madison, WI, USA. (Agronomy Monograph, 9).

Chien, S.H. 1978. Interpretation of Bray I-extractable phosphorus from acid soils treated with phosphate rocks. Soil Science 126: 34-39.

Chien, S.H.; Adams, F.; Khasawneh, F.E.; Henao, O. 1987. Effects of combinations of triple superphosphate and a reactive phosphate rock on yield and phosphorus uptake by corn. Soil Science Society of America Journal 51: 1656-1658.

Chien, S.H.; Clayton, W.R.; McClellan, G.M. 1980a. Kinetic dissolution of phosphate rocks in soils. Soil Science Society of America Journal 44: 260-264.
Chien, S.H.; Leon, L.A.; Tejeda, H. 1980b. Dissolution of North Carolina phosphate rock in acid Colombian soils as related to soil properties. Soil Science Society of America Journal 44: 1267-1271.

Christensen, H.H.; Posner, A.M. 1980. The interaction of phosphate with an anion exchange resin. Journal of Soil Science 31: 447-455.

Cross, A.F.; Schlesinger, W.H. 1995. A literature review and evaluation of the Hedley fractionation: applications to the biogeochemical cycles of soil phosphorus in natural ecosystems. Geoderma 64: 197-214.

Curtin, D.; Syers, J. K.; Sraillie, G.W. 1987. The importance of exchangeable cations and resin-sink characteristics in the release of soil phosphorus. Journal of Soil Science 38: 711-716.

Dewis, J.; Freitas, 1989. Physical and chemical methods of soil analysis. FAO, Rome, Italy. (FAO Soils Bulletin, 10).

Engelstad, O.P.; Jugsujinda, A.; De Datta, S.K. 1974. Response by flooded rice to phosphate rocks varying in citrate solubility. Soil Science Society of America Proceedings 38: 524-529.

Ernani, P.R.; Barber, S.A. 1995. Phosphorus availability in a low $\mathrm{pH}$ highly weathered soil as affected by added salts. Ciência Rural 25: 219-222.

Fox, R.L.; Kamprath E.J. 1970. Phosphate sorption isotherms for evaluating the phosphate requirements of soil. Soil Science Society of America Proceedings 34: 902-907.

Hartemink, A.E.; Buresh, R.J.; Jama, B.; Janssen, B.H. 1996. Soil nitrate and water dynamics in sesbania fallows, weed fallows and maize. Soil Science Society of America Journal 6: $568-574$.

He, Z.L.; Baligar, V.C.; Martens, D.C.; Ritchey, K.D.; Kemper, W.D. 1996b. Factors affecting phosphate rock dissolution in an acid soil amended with liming materials and cellulose. Soil Science Society of America Journal 60: 1596-1601.

He, Z.L.; Baligar, V.C.; Martens, D.C.; Ritchey, K.D.; Kemper, W.D. 1996a. Kinetics of phosphate rock dissolution in an acid soil amended with liming materials and cellulose. Soil Science Society of America Journal 60: 1589-1595.

Hedley, M.J.; Stewart, W.B.; Chauhan, B.S. 1982. Changes in inorganic and organic soil phosphorus fractions induced by cultivation practices and by laboratory incubations. Soil Science Society of America Journal 46: 970-976.

Ivarsson, K. 1990. The long-term soil fertility experiments in southern Sweden. IV. Changes in inorganic and organic soil after a pot trial. Acta Agriculturae Scandinavic 40: 205-215.

Kanabo, I.; Gilkes, R.J. 1987. The role of soil pH in the dissolution of phosphate rock fertilizers. Fertilizer Research 12: 165-174.

Khasawneh, F.E.; Doll, E.C. 1978. The use of phosphate rock for direct application to soils. Advances in Agronomy 30: 159-206.

Kihara J.; Martius, C.; Bationo, A.; Thuitaa M.; Lesueur, D.; Herrmann L.; Amelung, W.; Vlek, P.L.G. 2012 Soil aggregation and total diversity of bacteria and fungi in various tillage systems of sub-humid and semi-arid Kenya. Applied Soil Ecology 58: 12-20.

Kirk, G.J.D.; Nye, P.H. 1986. A simple model for predicting the rates of dissolution of sparingly soluble calcium phosphates in soil. III. A predictive model for regularly distributed particles. Journal of Soil Science 37: 511-524. 
Lindsay, W.L.; Vlek, P.L.G. 1977. Phosphate minerals. p. 639-672. In: Dixon, J.B.; Weed. S.B., eds. Minerals in soil environments. Soil Science Society of America, Madison, WI, USA.

MacKay, A.D.; Syers, J.K.; Tillman, R.W.; Gregg, P.E.H. 1986. A simple model to describe the dissolution of phosphate rock in soils. Soil Science Society of America Journal 50: 291-296.

MacKay, A.D.; Syers, J.K. 1986. Effect of phosphate, calcium, and $\mathrm{pH}$ on the dissolution of a phosphate rock in soil. Fertilizer Research 10: 175-184.

McLean, E.O. 1965. Soil pH and lime requirement. p. 199-223. In: Black, C.A.; Evans, D.P.; White, J.L.; Ensminger, L.E; Clark, F.E., eds. Methods of soil analysis. Part 2. American Society of Agronomy, Madison, WI, USA.

Menon, R.G.; Hammond, L.L,; Sissingh, H.A. 1989. Determination of plant available phosphorus by the iron hydroxide-impregnated filter paper (Pi) soil test. Soil Science Society of America Journal 53: 110-115.

Murphy, J.; Riley, J.P. 1962. A modified single solution method for the determination of phosphorus in natural waters. Analytica Chimica Acta 27: 31-36.

Mutuo, P.K.; Smithson, P.C.; Buresh, R.J.; Okalebo, R.J. 1999. Comparison of phosphate rock and triple superphosphate on a phosphorus-deficient Kenyan soil. Communication in Soil Science \& Plant Analysis 30: 1091-1103.

Naidu, R.; Syers, J.K.; Kirkman, J.H. 1990. Effect of liming on phosphate sorption by acid soils. Journal of Soil Science 41: 165-175.

Nelson, D.W.; Sommers, L.E.; 1985. Total carbon, organic carbon and organic. p. 539-579. In: Page, A.L., ed. Methods of soil analysis. Part 2. Chemical and microbiological properties. Soil Science Society of America, Madison, WI, USA.

Okalebo, J.R.; Gathua, K.W.; Woomer, P.L. 1993. Laboratory methods of plant and soil analysis: a working manual. KARI, SSEA, TSBF, UNESCO-ROSTA, Nairobi, Kenya.

Olsen, S.R.; Cole, C.V.; Watanabe, F.S.; Dean, L.A. 1954. Estimation of vailable phosphorus in soils by extraction with sodium bicarbonate. USDA, Washingtom, DC, USA. (Circular, 939).

Pissarides, A.J.; Stewart, W.B.; Reenie, D.A. 1968. Influence of cation saturation on phosphorus adsorption by selected clay minerals. Canadian Journal of Soil Science 48: 151-157.

Qain, P.Y.; Schoenau, J.J.; Huang, W.Z. 1992. Use ion exchange membranes in routine soil testing. Communication in Soil Science \& Plant Analysis 23: 1791-1804.

Robinson, J.S.; Syers, J.K. 1990. A critical evaluation of factors influencing the dissolution of Gafsa phosphate rock. Journal of Soil Science 41: 597-605.

Robinson, J.S.; Syers, J.K.; Bolan, N.S. 1992b. Importance of proton supply and calcium sink size in the dissolution of phosphate rock materials of different reactivity in soil. Journal of Soil Science 43: 447-459.

Sample, E.C.; Soper, R. J.; Racz, J.G. 1980. Reactions of phosphate fertilizers in soils. p. 263-310. In: Khasawneh, F.E.; Sample, E.C.; Kamprath, E.J., eds. The role of phosphorus in agriculture. ASA/CSSA/SSSA, Madison, WI, USA.

Sanyal, S.K.; Datta, S.K.D. 1991. Chemistry of phosphorous transformations in soil. Advances in Soil Science 16: 1-94.
Savini, I.; Smithson, P.C.; Karanja, N.K. 2006. Effects of added biomass, soil $\mathrm{pH}$ and calcium on the solubility of Minjingu phosphate rock in a Kenyan Oxisol. Archives of Agronomy and Soil Science 52: 19-36.

Schmidt, J.P.; Buol, S.W.; Kamprath, E.J. 1996. Soil phosphorus dynamics during seventeen years of continuous cultivation: Fractionation analysis. Soil Science Society of America Journal 60: $1168-1172$.

Sharpley, A.N. 1991. Soil phosphorus extracted by iron-aluminum line oxide-impregnated filter paper. Soil Science Society of America Journal 55: 1038-1041.

Sibbesen, E. 1978. An investigation of the anion-exchange resin method for soil phosphate extraction. Plant and Soil 50: 305321.

Skogley, E.O.; Georgins, S.J.; Yang, J.E.; Schaff, B.E. 1990. The phytoavailability soil test-P. Communication in Soil Science \& Plant Analysis 21: 1229-1243.

Sposito, G. 2008. The Surface Chemistry of Soils. Oxford University Press, New York, NY, USA.

Stoorvogel, J.J.; Smaling, E.M.A,; Jansen, B.H. 1993. Calculating soil nutrient balances in Africa at different scales. I. SupraNational scale. Fertilizer Research 35: 227-235.

Syers, J.K.; Harris, R.F.; Armstrong, D.E. 1973. Phosphate chemistry in lake sediments. Journal of Environmental Quality 2: $1-14$.

Tiessen, H.; Stewart, J.W.B.; Cole, C. V.1984. Pathways of Phosphorus Transformations in Soils of Differing Pedogenesis. Soil Science Society of America Journal 48: 853-858.

Tiessen, H.; Moir, J.O. 1993. Characterization of available phosphorus by sequential extraction. p. 76-86. In: Carter, M.R., ed. Soil sampling and methods of analysis. Lewis, Boca Raton, FL, USA.

Tunesi, S.; Poggi, V.; Gessa, C. 1999. Phosphate adsorption and precipitation in calcareous soils: the role of calcium ions in solution and carbonate minerals. Nutrient Cycling in Agroecosystems 53: 219-227

United States Department of Agriculture [USDA]. 1992. Soil Taxonomy. Washington, DC, USA. (Agriculture Handbook, 294).

Walker, T.W.; Syers, J.K. 1976. The fate of phosphorus during pedogenesis. Geoderma 15: 1-19.

Wiklander, L. 1964. Cation and anion exchange phenomena. p. 163-205. In: Bear, F.E., ed. Chemistry of the soil. Reinhold, New York, NY, USA.

Wilson, M.A.; Ellis, B.G. 1984. Influence of calcium solution activity and surface area on the solubility of selected rock phosphates. Soil Science 138: 354-359.

Zapata, F.; Zaharah, A.R. 2002. Phosphorus availability from phosphate rock and sewage sludge as influenced by the addition of water-soluble phosphate fertilizer. Nutrient Cycling in Agroecosystems 63: 43-48.

Zee, S.E.A.T.M. van der; Fokkink, L.G.J.; Riemsdijk, W.H. van. 1987. A new technique for assessment of reversibly adsorbed phosphate. Soil Science Society of America Journal 51: 599604. 